\title{
Placenta praevia: percreta and accreta, our experience
}

\author{
Preeti F. Lewis*, Shreya Chinchoriya
}

Department of Obstetrics and Gynecology, Grant Medical College and JJ Group of Hospitals, Mumbai, Maharashtra, India

Received: 17 December 2019

Revised: 23 January 2020

Accepted: 27 January 2020

\author{
*Correspondence: \\ Dr. Preeti Lewis, \\ E-mail: plewisin@gmail.com
}

Copyright: (C) the author(s), publisher and licensee Medip Academy. This is an open-access article distributed under the terms of the Creative Commons Attribution Non-Commercial License, which permits unrestricted non-commercial use, distribution, and reproduction in any medium, provided the original work is properly cited.

\section{ABSTRACT}

Background: Morbidly adherent placenta has an increasing incidence over decades. The purpose of this study is to identify risk factors and etiology of placenta previa- accreta and percreta.

Methods: A cross sectional observational study of patients with morbidly adherent placenta previa including placenta accreta and placenta percreta were studied over a period of three years from June 2017 to June 2019 in a tertiary care centre, Mumbai.

Results: Cases showed a higher incidence in patients with previous cesarean delivery (CS), grandmultiparity, abortions without the history of check curettage and anterior/central placentae.

Conclusions: History of uterine surgeries and previous cesarean are some important risk factors for accreta in placenta previa patients.

Keywords: Abortion, Caesarean, Check curettage, Placenta accreta, Placenta percreta, Previous surgery

\section{INTRODUCTION}

Placenta accreta as described by Irving et al, is "failure of separation of the placenta from the uterine wall following delivery of the human fetus leading to the often-used term morbid placental adherence". 1 The condition is characterised by placental invasion thereby leading to torrential haemorrhage. It has been proposed that the terminology, placenta accreta spectrum (PAS), including accreta, increta, and percreta be used hence forth. ${ }^{2}$

The condition has not yet been detected in any other animal in the literature till date. ${ }^{3}$

The incidence of PAS has increased substantially from 0.8 per 1000 deliveries in the 1980 s to 3 per 1000 deliveries in the past decade, a phenomenon may be because of a rising caesarean section rate worldwide. ${ }^{4}$
PAS is associated with significant maternal morbidity and mortality, majorly including obstetric haemorrhage and obstetric hysterectomy. ${ }^{5}$ Mortality rates of up to $7 \%$, associated with PAS are reported. ${ }^{6}$ The most recent confidential inquiry into maternal mortality in the United Kingdom (MMBRACE-UK, 2017) highlighted the continued high maternal mortality associated with PAS. ${ }^{7}$

The most important antenatal risk factor for PAS is the number of previous caesarean sections. In the presence of low-lying placenta (placenta previa) and three previous caesarean sections, it is estimated that a woman would have a $61 \%$ risk of PAS. ${ }^{8}$ Antenatal diagnosis is a key element in order to improve maternal and perinatal outcome. Despite ultrasound and MRI having improved antenatal diagnosis, between one half and two thirds of cases remain undiagnosed, resulting in poorer maternal outcomes. ${ }^{9,10}$ 
The risk factors for placenta previa are smoking, previous caesarean sections, advanced maternal age, multiparity and conception by in vitro fertilization (IVF). ${ }^{11}$

Abortions are mainly associated with foetal pathology, congenital abnormality, low birth weight and preterm labour in subsequent pregnancies. ${ }^{12}$

Primary and secondary uterine pathologies which have been associated with PAS include direct surgical scar including caesarean delivery, surgical termination of pregnancy, dilatation and curettage, myomectomy, endometrial resection, Asherman's syndrome and nonsurgical scar including IVF procedures, uterine artery embolization, chemotherapy and radiation, endometritis intra-uterine device, manual removal of placenta and previous accrete.

Certain uterine anomalies associated include bicornuate uterus, adenomyosis, submucous fibroids and myotonic dystrophy.

\section{METHODS}

This was a cross sectional observational study done from June 2017 to June 2019 at obstetrics and gynaecology department at a tertiary care centre, Mumbai. All the antenatal patients who visited the tertiary care centre underwent ultrasonography with placental localization.

Study design - cross sectional observational study.

\section{Inclusion criteria}

- ANCs of all age groups who were diagnosed on ultrasonography to be placenta accreta spectrum and were confirmed intra operatively.

\section{Exclusion criteria}

- The cases with a normally located placenta were excluded.

A detailed history and examination of the patients was done. The patients were kept for close follow up and MRI was done in some selected cases. A cross sectional study was done to analyse the most common risk factors contributing to the etiology of the placnetal accreta syndrome. In cases of past surgeries like check curettage, previous caesarean sections, the incidence was seen and compared with patients not having any such history and hence the role of surgeries as an etiology factor was assessed.

\section{RESULTS}

Placenta accreta spectrum is a major cause of maternal morbidity and mortality. It is one of the leading causes of obstetric haemorrhage. A total of 19 cases were studied.

\section{Age distribution}

The results support the fact that the incidence increases as the age advances. Most of the cases were found in the age group $>35$ years of age $(52.64 \%)$.

The cases of PAS in the age group of 20-35 years were $47.36 \%$ and in women more than 35 years age group were $52.64 \%$. The risk of placenta percreta and accreta increases as the parity increases and is associated with increased risk of caesarean sections. When compared with placenta previa cases, a higher incidence of placenta previa was found in the age group of 20-35 years $(73.75 \%)$, whereas the placenta accrete syndrome had a higher incidence in age group > 35 years $(52.64 \%)$.

Table 1: Age wise distribution of cases.

\begin{tabular}{|ll|lll|}
\hline Age & No. of cases (PAS) & Percentage (PAS) & No. of previa cases & Percentage of previa cases \\
\hline$<$ 20 years & 0 & 0 & 3 & 3.75 \\
\hline 20-35 years & 9 & 47.36 & 59 & 73.75 \\
\hline$>$ 35 years & 10 & 52.64 & 18 & 22.5 \\
\hline Total & $\mathbf{1 9}$ & $\mathbf{1 0 0}$ & $\mathbf{8 0}$ & $\mathbf{1 0 0}$ \\
\hline
\end{tabular}

\section{Previous caesarean sections}

The cases of PAS in previously unscarred uterus were $15.78 \%$, in previous one LSCS were $57.89 \%$, in previous 2 LSCS were $15.78 \%$ and in women with more than previous 2 LSCS were $10.55 \%$.

A total 16 cases had history of transfusion of blood and blood products $(94.73 \%)$.
Most of the cases were shifted under critical care unit for post-operative monitoring. The perinatal outcomes were satisfactory and only 2 cases with perinatal mortality.

\section{Indication of previous caesarean sections}

In case of previous caesarean sections, the commonest indication of previous caesarean sections included fetal distress $(n=3)$, failure of induction $(n=2)$, and previous caesarean with a short inter-conception period $(n=2)$. 
Table 3: Indication of previous caesarean section.

\begin{tabular}{|l|l|}
\hline $\begin{array}{l}\text { Indication of previous caesarean } \\
\text { section }\end{array}$ & $\begin{array}{l}\text { No. of } \\
\text { cases }\end{array}$ \\
\hline Fetal distress & 3 \\
\hline Two tight loops of cord around neck & 1 \\
\hline Prolonged PROM & 1 \\
\hline Transverse lie & 2 \\
\hline breech & 2 \\
\hline Big baby & 1 \\
\hline Failure of induction & 2 \\
\hline Previous caesarean section & 2 \\
\hline oligohydramnios & 1 \\
\hline
\end{tabular}

\section{Check curettage}

Patient having history of check curettage following induced abortion or spontaneous abortion had a higher incidence of placenta previa but as far as co-relation with the incidence of placenta accrete/percreta and history of check curettage is considered, the incidence of PAS in patients not undergoing check curettage is around $35 \%$ and patients undergoing check curettage is $11 \%$. A patient with history of abortion not followed by check curettage had a higher risk of placenta accrete syndrome than with the patients undergoing check curettage (relative risk of 0.3294).

Table 4: Risk association between PAS and cases without history of check curettage.

\begin{tabular}{|lll|}
\hline $\begin{array}{l}\text { History of check } \\
\text { curettage }\end{array}$ & $\begin{array}{l}\text { No. of cases } \\
\text { of PAS }\end{array}$ & $\begin{array}{l}\text { No. of placenta } \\
\text { previa cases }\end{array}$ \\
\hline Yes & 2 & 15 \\
\hline No & 5 & 9 \\
\hline
\end{tabular}

\section{DISCUSSION}

The placenta accrete spectrum constitutes an important cause of adverse maternal and perinatal morbidity and mortality outcomes.

In the present study most of the cases were associated with advanced age, hence advance maternal age is an important risk factor for placenta accrete and percreta. This is in concordance with the study done by Williams MA et al. Among older women, there may be compromised uteroplacental blood flow. The microscopic studies of placentae from older women have revealed uteroplacental under perfusion and large placental infarcts in older women. ${ }^{13}$ It could be as a result of endometrial scarring at the site of prior placental attachments resulting in lower placental implantation, other possibility may be due to atherosclerotic changes of blood vessels which leads to decreased uteroplacental blood flow, which in turn leads to large placenta encroaching on the cervical os with repeated pregnancies.
The current study shows that the incidence of percreta/ accreta increases as the rate of caesarean sections increases as has been shown by the studies done by Ananth CV et al, Faiz AS et al, Getahun D, Oyelese Y, et al. ${ }^{14-16}$ There were 5 cases of percreta and 14 cases of accrete.

Most studies have reported a dose related response pattern of risk factors of placenta previa with increasing number of previous caesarean sections. ${ }^{17}$ The previous caesarean delivery include polyp formation, lymphocyte infiltration, capillary dilatation, and infiltration of the endometrial tissue that surround the scar by free red blood cells, thereby increasing the chances of placenta accrete syndrome. ${ }^{18}$

\section{CONCLUSION}

The current study shows that the risk factors of placenta accreta and percreta to be advanced maternal age, previous delivery by $\mathrm{C} / \mathrm{S}$, bleeding during pregnancy and multiparty. history of uterine surgeries and previous caesarean are some important risk factors for accreta in placenta previa patients. A positive correlation was obtained between history of induced abortion /spontaneous abortion without check curettage and incidence of placenta accrete/percreta in this study. However, results of this study are not statistically conclusive because of small sample size and further studies are required.

\section{Funding: No funding sources \\ Conflict of interest: None declared \\ Ethical approval: Not required}

\section{REFERENCES}

1. Irving C, Hertig AT. A study of placenta accrete. Surg Gynecol Obstet. 1937;38(6):1088-200.

2. Jauniaux E, Chantraine F, Silver RM, Langhoff-Roos J. For the FIGO Placenta Accreta Diagnosis and Management Expert Consensus Panel. FIGO consensus guidelines on placenta accreta spectrum disorders: epidemiology. Int J Gynecol Obstet. 2018;140(3):265-73.

3. Chuong E. Evolutionary perspectives into placental biology and disease. AppliedTranslat Genom. 2013;2:64-9.

4. Higgins M, Monteith C, Foley M, and O'Herlihy C. Real increasing incidence of hysterectomy for placenta accreta following previous caesarean section. Eur J Obstet Gynecol Repro Biol. 2013;171(1):54-6.

5. Silver RM, Barbour KD. Placenta accreta spectrum: accreta, increta, and percreta. Obstet Gynecol Clin North Am. 2015;42(2):381-402.

6. O'Brien JM, Barton JR, Donaldson ES. The management of placenta percreta: conservative and operative strategies. Am J Obstet Gynecol. 1996;175(6):1632-8. 
7. Knight M, Nair M, Tuffnell D, Shakespeare J, Kenyon S, Kurinczuk JJ. Saving lives, improving mothers' care: lessons learned to inform maternity care from the UK and Ireland confidential enquiries into maternal deaths and morbidity 2013-15. National Perinat Epidemiol Unit. University of Oxford: Oxford. 2017:1-10.

8. Placenta Praevia, Placenta Praevia Accreta and Vasa Praevia: Diagnosis and Management (Green-top Guideline No. 27), Royal College of Obstetricians and Gynaecologists, 2011;1-26.

9. Bailit JL, Grobman W, Rice MM, Reddy UM, Wapner RJ, Varner MW, et al. Morbidly adherent placenta treatments and outcomes. Obstet Gynecol. 2015;125(3):683.

10. Fitzpatrick KE, Sellers S, Spark P, Kurinczuk JJ, Brocklehurst $\mathrm{P}$, Knight $\mathrm{M}$. The management and outcomes of placenta accreta, increta, and percreta in the UK: a population-based descriptive study. BJOG: Int J Obstet Gynaecol. 2014;121(1):62-71.

11. Shobeiri F, Jenabi E, Karami M, Karimi S. Determinants of placenta previa: a case-control study. Biomed Res Therapy. 2017;4:1411-9.

12. Kashanian M, Akbarian A, Baradaran $H$, Shabandoust S. Pregnancy outcome following a previous spontaneous abortion (miscarriage). Gynecol Obstet Invest. 2006;61:167-70.

13. Eniola AO, Bako AU, Selo-Ojeme DO. Risk factors for placenta previa in Southern Nigeria. East Afr Med J. 2002;79:535-8.
14. Wax JR, Seiler A, Horowitz S, Ingardia CJ. Interpregnancy interval as a risk factor for placenta accreta. Connecticut Med. 2000;64(11):659-61.

15. Mehboob R, Ahmed N. Fetal outcome in major placenta previa. J Med Res. 2003;42:372-38.

16. Francois K, Johuson JM. Is placenta previa more common in multiple pregnancy? Am J Obstet Gynecol. 2002;79:535-8.

17. Mortensen JT, Thulstrup AM, Larsen H, Møller M, Sørensen HT. Smoking, fetal sex, and risk of placental abruption, placenta previa, and preeclampsia: a population - based cohort study. Acta Obstet Gynecol Scand. 2001;10:894-8.

18. Yang Q, Wen SW, Oppenheimer L, Chen XK, Black $\mathrm{D}$, Gao J, et al. Association of caesarean delivery for first birth with placenta praevia and placental abruption in second pregnancy. BJOG: An Int J Obstet Gynaecol. 2007;114(5):609-13.

Cite this article as: Lewis PF, Chinchoriya S.

Placenta praevia: percreta and accreta, our experience. Int J Reprod Contracept Obstet Gynecol 2020;9:928-31. 